\title{
Empathy enhancement through group play therapy to reduce aggressive behavior
}

\author{
Iswinarti Iswinarti ${ }^{\left.1^{*}\right)}$, Nurul Hidayah ${ }^{2}$ \\ ${ }^{12}$ Psychology Department, Universitas Muhammadiyah Malang, Indonesia
}

\begin{tabular}{l}
\hline Article Info \\
\hline Article history: \\
Received Jul 01st, 2020 \\
Revised Aug 05th, 2020 \\
Accepted Sep 20th, 2020 \\
\end{tabular}

\section{Keyword:}

Group play therapy

Empathy

Aggressive behavior

School-aged children

Random assignment

\begin{abstract}
Aggressive behavior in children has negative impacts on their social life. The various intervention programs were used to reduce aggressive behavior, one of them was by enhancing children's empathy. Group Play Therapy is used to enhance children's empathy ability so that their aggressiveness level can decrease. This study aimed to enhance empathy through Group Play Therapy in children who had aggressive behavior. Experimental research was used with pre-test and post-test design in two different groups, the experimental and control groups. The subjects were twenty school-aged children. The subject's criteria for having a moderate-low level of empathy, also having moderate-high levels of aggressiveness. The instruments were The LA Aggression Scale for Elementary School and Upper Secondary School Students to measure the aggression levels with Cronbach's Alpha value is 0,879 . The instrument used to measure the children's empathy was The Empathy Questionnaire for Children and Adolescents (EmQue-CA) with Cronbach's Alpha value is 0,828 . The Wilcoxon, Mann-Whitney, and Kendall's Tau tests were used to analyze data. The results showed that Group Play Therapy can enhance children's empathy so that it can reduce aggressive behavior.
\end{abstract}

\section{Corresponding Author:}

Iswinarti Iswinarti,

Universitas Muhammadiyah Malang

Email: iswinarti.psi@gmail.com

\section{Pendahuluan}

Agresivitas pada anak-anak bukan hanya fenomena yang mengkhawatirkan, tetapi masalah sosial, psikologis, dan pedagogis yang sangat serius (Parfilova, 2016). Pola perilaku agresi yang terbentuk di masa kecil akan berlanjut sampai dewasa dengan konsekuensi negatif yang menyertainya (Reef et al., 2011). Tingkat agresi fisik yang tinggi di masa anak-anak juga memprediksi kriminalitas di masa depan (Pingault et al., 2013).

Perilaku agresi di lingkungan sekolah memiliki dampak yang luas pada interaksi sosial individu, status sosial, dan konsep diri yang menyebabkan hubungan dan persahabatan yang buruk (Breet et al., 2010). Perilaku agresi yang ditunjukkan pada masa kanak-kanak dan tidak mendapatkan penanganan yang tepat, maka perilaku tersebut dapat berlanjut sampai akhir masa remaja dan dewasa (Vitaro et al., 2002). Anak-anak dengan tingkat agresivitas tinggi lebih cenderung berperilaku mengganggu di sekolah. Mereka mengganggu anak-anak lainnya dan mengakibatkan mereka dapat dikeluarkan dari sekolah (Hudley et al., 1998). Jika orang tua maupun guru tidak memberikan perhatian secara serius terhadap perilaku tersebut, maka perilaku agresi akan meningkat dan cenderung bertahan selama fase perkembangan dan membuat anak-anak mengembangkan perilaku agresi dalam hubungan sosial dan komunikasi dengan individu lainnya (Botha, 2014). 
Pengembangan kemampuan empati dan perilaku prososial individu penting untuk menghambat tindakan agresi terhadap anak-anak usia sekolah lainnya (Scrimgeour, 2007). Pengembangan kemampuan empati pada anak-anak sangat penting untuk memotivasi perilaku prososial, termasuk mematuhi aturan sosial, dan terlibat dalam perilaku altruistik. Kemampuan empati juga memfasilitasi pengembangan kompetensi sosial dan meningkatkan kualitas hubungan yang bermakna dengan orang lain (Mcdonald \& Messinger,2011).

Menurut Bandura salah satu penyebab terbentuknya agresi pada anak, agresi fisik maupun verbal yaitu melalui imitasi atau meniru orang lain (Bandura, Ross, \& Ross, 1961). Anak-anak belajar bersikap dan berperilaku termasuk pula perilaku agresi melalui interaksi dengan orang sekitarnya. Video games yang mengandung unsur kekerasan dapat pula menyebabkan masalah perilaku agresi dan eksternalisasi pada anakanak ataupun pada masa awal remaja (Milani et al., 2015). Perbedaan gender juga berpengaruh secara signifikan terhadap perilaku agresi. Anak laki-laki yang terpengaruh oleh kartun televisi yang berorientasi pada kekerasan menunjukkan perilaku agresi yang lebih besar dari anak perempuan (Ergün, 2012).

Sekolah merupakan tempat yang paling penting di luar rumah, dimana persepsi, sikap, dan perilaku terbentuk di awal masa perkembangan anak (UNICEF, 2006). Hal tersebut menjadikan lingkungan sekolah menjadi lingkungan yang baik untuk mengidentifikasi dan menyediakan intervensi dini yang ditargetkan untuk anak-anak dengan tingkat perilaku agresi yang tinggi. Identifikasi dini anak dengan perilaku agresi dan intervensi yang tepat, sangat penting dilakukan untuk mencegah dan menangani perilaku agresi di sekolah (Pingault et al., 2013). Beberapa program intervensi dini yang mendesain pelatihan untuk orang tua siswa, pelatihan keterampilan sosial untuk anak dengan dukungan dari guru menunjukkan hasil yang baik (Wilson \& Lipsey, 2008). Hasil penemuan tentang intervensi berbasis sekolah untuk perilaku agresi menunjukkan bahwa hasil intervensi yang terbaik terjadi ketika difokuskan pada siswa dengan risiko perilaku agresi tertinggi (Hudley et al., 1998). Intervensi di sekolah dapat dilakukan melalui pembelajaran sosio-emosional. Intervensi yang berfokus pada pembelajaran sosial dan emosional telah menunjukkan efektivitas untuk mengurangi perilaku agresi dan meningkatkan perilaku prososial (Schonert-Reichl, Oberle, Lawlor, Abbott \& Oberlander, 2012).

Pada penelitian sebelumnya, intervensi pada perilaku agresi menggunakan anger management ternyata tidak cukup memberikan efek pada penurunan perilaku agresi (Siddiqah, 2010). Durasi pelaksanaan intervensi ataupun jumlah sesi menjadi faktor yang mempengaruhi hasil akhir dari perubahan perilaku setelah intervensi. Anger management menggunakan delapan sesi dalam intervensi tanpa sesi tambahan atau materi pelengkap lain. Hal tersebut menjadi faktor kurang mampunya anger management dalam memberikan dampak perubahan perilaku agresi pada anak-anak.

Adanya peningkatan kemampuan seseorang dalam mengelola amarahnya tidak selalu seiring dengan menurunnya perilaku agresi (Siddiqah, 2010). Jenis intervensi lain yang dapat digunakan untuk menurunkan perilaku agresi yaitu melalui terapi bermain. Terapi bermain dapat membantu anak-anak bermasalah mengatasi peristiwa sulit yang mereka hadapi. Bermain digunakan sebagai media komunikasi karena hal tersebut merupakan cara anak-anak memahami dunia mereka (Cattanach, 2003).

Penelitian lain menggunakan media Buku "Pelangi Hatiku" (BPH) untuk menurunkan agresi. Intervensi yang diberikan dengan media $\mathrm{BPH}$ memberikan efek penurunan tingkat agresivitas anak-anak. Namun peneliti menyatakan BPH perlu diberikan dalam waktu yang cukup panjang semisal satu semester atau lebih sehingga efektivitasnya akan dapat terlihat (Ali \& Utami, 2013). Program intervensi lainnya yang juga untuk menurunkan agresi yaitu Assertive Behavior Therapy. Intervensi tersebut menunjukkan adanya penurunan agresi pada anak terutama agresi verbal. Kelemahan penelitian tersebut terletak pada sedikitnya jumlah subjek (lima orang) dan sesi yang kurang bervariatif (Stevani, Basaria, \& Irena, 2018).

Intervensi lain yang dapat digunakan untuk menurunkan perilaku agresi adalah dengan media bermain. Bermain merupakan sarana yang dapat digunakan dalam terapi untuk berbagai tujuan. Permainan yang digunakan dalam terapi tergantung pada kemampuan anak untuk menggunakan alat bermain, tingkat perkembangan, usia, kemampuan untuk verbalisasi, dan intervensi secara keseluruhan (Russ, 2004). Play Therapy digunakan oleh terapis maupun klinisi sebagai sarana untuk membantu anak-anak menghadapi masalah emosional dan perilaku mereka (Drewes \& Schaefer, 2010).

Terapi bermain memiliki beberapa variasi yang digunakan berdasarkan kasus dan tujuan intervensi. Terapi bermain dengan metode kognitif behavioral dapat digunakan untuk meningkatkan fungsi komunikatif anakanak (Maryam et al., 2014). Group art therapy efektif untuk mengurangi kecenderungan agresi verbal dan menumbuhkan keinginan untuk saling menaati peraturan, bersosialisasi, bermain dan bekerja sama pada anak (Hanan et al., 2018). Child-centered play therapy dapat memberikan dampak terhadap penurunan perilaku agresi secara signifikan (Ray et al., 2009). Play Therapy mengambil peranan penting dalam ilmu psikologi dan 
sosial terutama pada perkembangan masa kanak-kanak. Play therapy dimanfaatkan oleh klinisi dalam membantu anak untuk menyelesaikan konflik psikologis dan meningkatkan pertumbuhan emosi (Wiley, 2001).

Suatu penelitian menunjukkan bahwa Group Play Therapy dapat mengurangi jumlah agresi pada anakanak secara umum dan secara khusus mengurangi agresi anak-anak pra-sekolah (Zand et al., 2015). Group Play Therapy juga dapat menurunkan agresi dalam komponen fisik dan verbal pada anak-anak di sekolah dasar (Sarpoulaki \& Kolahi, 2016). Dapat dikatakan bahwa Group Play Therapy memberikan efek pada penurunan agresivitas. Penelitian ini menggunakan intervensi Group Play Therapy untuk meningkatkan empati anak yang memiliki ciri-ciri perilaku agresi. Hasil akhir yang ingin dicapai melalui intervensi tersebut yaitu menurunnya perilaku agresi.

Group Play Therapy yang dapat meningkatkan kemampuan empati pada anak adalah permainan yang sesuai dengan lingkungan mereka di mana anak-anak dapat mengukur kemampuan mereka sendiri, mengekspresikan diri mereka, dan permainan yang dilakukan sesuai dengan usia mereka (Chinekesh et al., 2014). Salah satu bentuk Group Play Therapy yang berkembang di Indonesia adalah permainan tradisional. Permainan tradisional erat hubungannya dengan perkembangan anak dalam hal sosial, emosi, intelektual, serta kepribadian (Iswinarti, 2010).

Tujuan penelitian ini adalah untuk meningkatkan empati melalui Group Play Therapy pada anak yang memiliki perilaku agresi. Manfaat dari penelitian ini adalah dapat membantu anak belajar untuk membangun rasa empati kepada orang lain melalui permainan. Guru dan orang tua dapat mengetahui bagaimana cara meningkatkan empati melalui permainan tradisional dan mengajarkan nilai-nilai positif yang terdapat dalam permainan untuk anak didik. Meningkatnya empati memungkinkan terjadinya penurunan perilaku agresi pada anak, membantu anak untuk saling menghargai, menghormati dan peduli terhadap temannya sehingga menurunkan perilaku agresi. Hasil dari penelitian ini nantinya bermanfaat sebagai bahan rujukan dalam perancangan rencana intervensi perilaku agresi pada anak.

\section{Metode}

\section{Desain}

Penelitian eksperimental digunakan dengan desain pre-test dan post-test pada dua kelompok beda, yaitu kelompok eksperimen dan kontrol. Metode eksperimental memungkinkan adanya perbandingan suatu efek perlakuan perlakuan pada variabel dependen. Perbandingan dilakukan pada hasil awal dan akhir setelah dilakukan eksperimen. Data hasil penelitian diperkaya dengan data wawancara dan observasi yang diperoleh sebelum dan sesudah dilakukan eksperimen, sehingga dapat memberikan hasil yang lebih komprehensif tentang proses eksperimen.

\section{Subjek}

Anak sekolah dasar usia antara 10-12 tahun dipilih sebagai subjek penelitian berdasarkan rekomendasi dari guru. Kriteria subjek yang digunakanyang memiliki skor perilaku agresi tingkat sedang-tinggi serta tingkat empati sedang-rendah. Screening dilakukan kepada anak-anak hingga diperoleh 20 anak yang memenuhi kriteria untuk dilibatkan dalam eksperimen. Kelompok eksperimen terdiri atas 10 anak dan kelompok kontrol juga terdiri atas 10 orang. Pengelompokan subjek dilakukan menggunakan random assignment.

\section{Instrumen}

Instrumen penelitian menggunakan skala agresi The LA Aggression Scale for Elementary School and Upper Secondary School Students yang disusun oleh Kozina yang memiliki empat aspek yaitu internal aggression, physical aggression, verbal agression, aggression towards authority (Kozina, 2013) dengan nilai Cronbach's Alpha sebesar 0,879. Instrumen tersebut digunakan untuk menentukan subjek penelitian maupun mengukur skor perilaku agresi baik sebelum ataupun sesudah diberikan intervensi.

Adapun skala yang digunakan sebagai pre-test dan post-test menggunakan skala empati The Empathy Questionnaire for Children and Adolescents (EmQue-CA) yang disusun oleh Overgaauw, Rieffe, Broekhof, Crone, dan Güroglu. Skala tersebut memiliki tiga aspek affective empathy, cognitive empathy, intention to comfort (Overgaauw et al., 2017). Skala EmQue-CA memiliki nilai Cronbach's Alpha sebesar 0,828.

\section{Prosedur pelaksanaan}

Beberapa tahapan pelaksanaan penelitian diuraikan sebagai berikut: 1) Tahap pertama, dilakukan dengan pemilihan subjek dengan mengisi skala The LA Aggression Scale dan skala EmQue-CA; 2) Tabulasi data, untuk mengelompokkan subjek dalam kategori skor agresi sedang hingga tinggi; 3) Pembagian kelompok, subjek dibagi untuk masuk kelompok eksperimen ataupun kelompok kontrol; 4) Perijinan ijin kepada orang 
tua anak-anak yang akan menjadi subjek penelitian. Poin penting dalam perijinan tersebut yaitu orang tua mengijinkan anaknya mengikuti proses penelitian dari awal hingga akhir; 5) Mengundang partisipan dari kelompok eksperimen untuk bermain sebagai bentuk intervensi; 6) Pelaksanaan, intervensi diberikan kepada subjek di kelompok eksperimen sebanyak tujuh sesi, yang diuraikan sebagai berikut:

Sesi 1: Membangun raport dan contract. Di dalam sesi 1 subjek dijelaskan mengenai tujuan, aturan, dan komitmen di dalam kelompok. Terapis membangun hubungan dan komunikasi dengan subjek di dalam kelompok.

Sesi 2: Permainan Gobak Sodor. Permainan tersebut dilakukan sesuai dengan aspek cognitive empathy. Permainan Gobak Sodor bermanfaat untuk melatih kejujuran, kepatuhan, kerja sama, tanggung jawab, ketangkasan, dan mengembangkan kemampuan berpikir logis, kritis, dan inovatif.

Sesi 3: Permainan Bola bergilir "bermain bersamamu". Permainan tersebut sesuai dengan aspek affective empathy dan intention to comfort. Tujuan dilakukan permainan tersebut untuk mendengarkan, mengemukakan, dan menghargai pendapat, serta membangun komunikasi.

Sesi 4: Permainan botol berputar :berbagi bersamamu", yang termasuk dalam aspek affective empathy dan intention to comfort. Tujuan pelaksanaan sesi ini yaitu unutk mengajarkan berbagi dan kepedulian.

Sesi 5: Permainan Ular Naga/ Oray-orayan, termasuk dalam aspek cognitive empathy. Tujuan permainan tersebut yaitu untuk melatih komunikasi, menghargai orang lain, dan mengajarkan tentang kebersamaan.

Sesi 6: Permainan Bentengan. Permainan tersebut juga untuk mengungkap aspek cognitive empathy. Manfaat yang diperoleh dari permainan tersebut yaitu untuk mengajarkan tentang menghargai, kerja sama, bersosialisasi, disiplin, dan mengembangkan kreativitas.

Sesi 7: Terminasi. Kegiatan tersebut bertujuan untuk mengakhiri sesi terapi. Pada saat tersebut anak-anak sebagai subjek penelitian dapat menjelaskan perubahan apa saja yang dirasakan, serta memberikan motivasi kepada anak-anak.

7) Subjek di kelompok kontrol tidak diberikan terapi; 8) Tahapan terakhir, partisipan diberikan post-test skala The LA Aggression Scale dan skala EmQue-CA. Pemberian skala tersebut bertujuan untuk melihat pengaruh setelah diberikannya intervensi. Skala diberikan kepada subjek di kelompok eksperimen maupun kontrol.

\section{Hasil Penelitian dan Pembahasan}

Setelah semua data dikumpulkan, peneliti menganalisa hasil data yang diperoleh dari para subjek dengan menggunakan uji Wilcoxon. Pengujian tersebut dilakukan untuk membandingkan hasil antara pre-test dan posttest baik di kelompok eksperimen maupun kontrol. Pengujian lain dilakukan untuk membandingkan kelompok eksperimen dan kontrol. Pengujian tersebut menggunakan uji Mann Whitney. Penelitian ini dilakukan selama dua pekan dengan pertemuan sebanyak tujuh sesi terapi. Adapun karakteristik subjek disajikan di Tabel 1.

Tabel 1. Deskripsi Karakteristik Subjek

\begin{tabular}{lll}
\hline Karakteristik Demografis & $\begin{array}{l}\text { Kelompok } \\
\text { Eksperimen }(\mathrm{N}=10)\end{array}$ & Kontrol $(\mathrm{N}=10)$ \\
\hline Gender & $5(50 \%)$ & $3(30 \%)$ \\
$\quad$ Perempuan & $5(50 \%)$ & $7(70 \%)$ \\
Laki-laki & & \\
Usia & $3(30 \%)$ & $7(70 \%)$ \\
10 tahun & $7(70 \%)$ & $1(10 \%)$ \\
11 tahun & - & $2(20 \%)$ \\
12 tahun & & \\
\hline
\end{tabular}

Uji homogenitas menggunakan Mann Whitney dilakukan pada data hasil skala perilaku agresi dan empati sebelum diberikan intervensi. Uji tersebut dilakukan untuk melihat kesamaan varian data baik di kelompok eksperimen maupun kontrol. Hasil yang didapatkan bahwa tidak terdapat perbedaan perilaku agresi dan kemampuan empati kelompok eksperimen maupun kelompok kontrol (lihat diTabel 2). Hasil analisis pada skor perilaku agresi menunjukkan nilai $U=47,50, Z=-0,192$ dengan signifikansi $>0,05$ yang berarti bahwa tidak terdapat perbedaan perilaku agresi antara dua kelompok yang dibandingkan. Begitu juga pada skor kemampuan empati dengan nilai $U=49,00, Z=-0,076$ dan signifikansi $>0,05$ yang berarti bahwa tidak terdapat perbedaan kemampuan empati diantara dua kelompok beda. 
Tabel 2. Hasil Perbandingan Homogenitas Sebelum Intervensi

\begin{tabular}{llll}
\hline Faktor Pembanding & $\mathbf{N}$ & $\mathbf{U}$ & $\mathbf{Z}$ \\
\hline Perilaku agresi & 20 & 47,50 & $-0,192^{*}$ \\
Empati & 20 & 49,00 & $-0,076^{*}$ \\
\hline
\end{tabular}

Catatan: *)sig> 0,05

Hasil pengujian kemampuan empati dengan menggunakan Wilcoxon pada kelompok eksperimen menunjukkan nilai $Z$ sebesar $-2,807(<0,05)$ yang berarti ada pengaruh yang signifikan antara Group Play Therapy terhadap kemampuan empati pada anak. Pengaruh intervensi yang diberikan ditunjukkan dengan adanya peningkatan kemampuan empati yang signifikan pada kelompok eksperimen $\left(M_{p r e}=30,50\right.$; $M_{\text {post }}=41,90$ ). Hasil uji kelompok kontrol diketahui memperoleh nilai $Z-2,333$ dengan nilai sig $>0,05$. Sedangkan nilai mean pretest sebesar 30,60 dan mean postest sebesar 31,30 yang berarti bahwa terdapat perbedaan kemampuan empati antara pretest dan postest namun perbedaan tersebut tidak cukup signifikan..

Tabel 3. Hasil Analisis Kemampuan Empati

\begin{tabular}{|c|c|c|c|c|c|c|c|}
\hline \multirow[b]{2}{*}{ Kelompok } & \multirow[b]{2}{*}{$N$} & \multirow[b]{2}{*}{$\bar{X}$} & \multirow[b]{2}{*}{$S D$} & \multirow{2}{*}{$\begin{array}{l}\text { Wilcoxon } \\
Z \\
\end{array}$} & \multicolumn{2}{|c|}{ Mann-Whitney } & \multirow{2}{*}{$\frac{\text { Kendall's Tau }}{Z}$} \\
\hline & & & & & $U$ & $Z$ & \\
\hline Eksperimen & 10 & & & $-2,807^{*}$ & & & \\
\hline Pre-test & & 30.50 & 3.779 & & & & \\
\hline Post-test & & 41.90 & 7.264 & & & & \\
\hline Kontrol & 10 & & & $-2,333^{*}$ & 9,000 & $-3,105^{*}$ & $-0,595^{*}$ \\
\hline Pre-test & & 30.60 & 4.115 & & & & \\
\hline Post-test & & 31.30 & 4.270 & & & & \\
\hline
\end{tabular}

Catatan: *)sig $<0,05 ; * *)$ sig $<0,001$

Berdasarkan pengujian skala kemampuan empati melalui Mann Whitney hasil menunjukkan nilai $U=9,000$, $Z=-3,105$ dan signifikansi $<0,05$ yang berarti bahwa terdapat perbedaan yang signifikan nilai kemampuan empati yang dilakukan antara kelompok eksperimen dan kontrol setelah intervensi. Dengan demikian pemberian intervensi menggunakan Group Play Therapy terbukti mampu meningkatkan kemampuan empati pada kelompok eksperimen. Uji regresi dilakukan untuk mengetahui pengaruh peningkatan kemampuan empati terhadap penurunan perilaku agresi yang dilakukan menggunakan uji Kendall’s Tau.

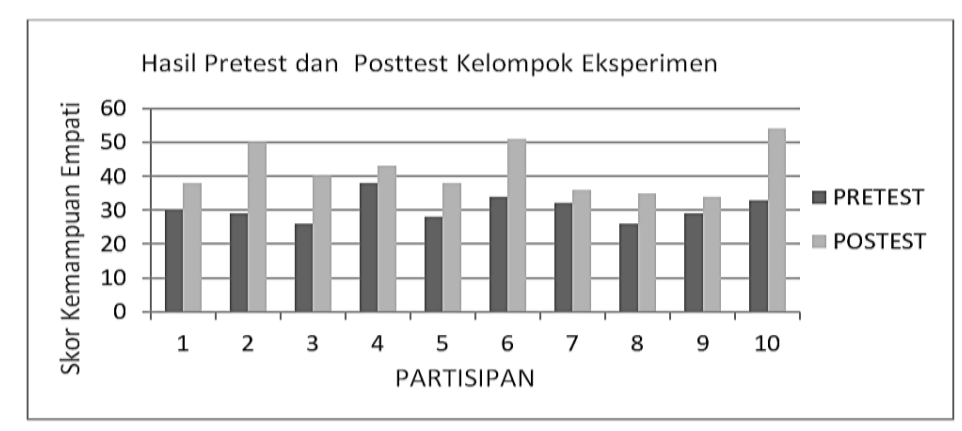

Gambar 1. Skor Kemampuan Empati Kelompok Eksperimen

Uji Kendall's Tau dilakukan guna mengetahui hubungan antara dua variabel berskala ordinal. Hasil menunjukkan nilai $Z=-0,595$ dengan signifikansi $<0,05$. Nilai $Z$ menunjukkan adanya hubungan negatif yang signifikan antara perilaku agresi dengan kemampuan empati anak. Keeratan kedua variabel perilaku agresi dan empati dapat dilihat pada nilai correlation coefficient sebesar -0.595. Berdasarkan norma dapat disimpulkan terdapat hubungan yang erat pada variabel perilaku agresi dengan empati dengan hubungan "negatif". Hubungan negatif atau tidak searah yang berarti bahwa semakin tinggi kemampuan empati anak maka semakin rendah nilai perilaku agresi. Hal ini menunjukkan bahwa peningkatan kemampuan empati dapat mempengaruhi penurunan perilaku agresi. 


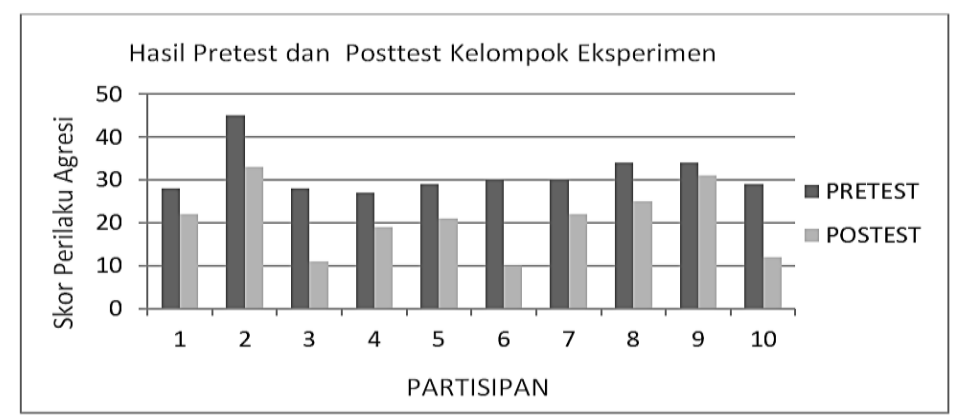

Gambar 2. Skor Perilaku Agresi Kelompok Eksperimen

Berdasarkan penelitian yang telah dilakukan diketahui bahwa Group Play Therapy dapat meningkatkan empati pada anak. Kelompok eksperimen mengalami perubahan yang signifikan pada perilaku agresi dan kemampuan empati yang mereka miliki. Manipulation check diberikan dengan cara melakukan wawancara. Hasil wawancara menunjukkan bahwa anak-anak belajar untuk lebih menghargai dan menyayangi teman, menahan diri dan mendengarkan ketika teman berbicara, belajar untuk tidak egois dan mematuhi peraturan dan pentingnya untuk peduli kepada teman dan bersikap baik kepada teman.

Pada awalnya anak-anak yang memiliki kecenderungan perilaku agresi menunjukkan perilaku yang kurang baik seperti sering memukul, mendorong atau mengolok teman sekelas ataupun di luar kelasnya. Anak-anak cenderung mudah marah dan menghardik jika keinginannya tidak dapat dipahami oleh temannya. Anak-anak ikut-ikutan mengolok atau memukul jika ada satu teman yang dipukul dan akhirnya menyebabkan perkelahian. Penelitian Scrimgeour menjelaskan bahwa pengembangan kemampuan empati dan perilaku prososial penting untuk menghentikan perilaku agresi terhadap orang lain bagi anak-anak di sekolah (Scrimgeour, 2007). Anak diajarkan untuk mengembangkan kemampuan empati agar dapat menjalin persahabatan dan bergaul dengan baik dengan teman di sekolah dengan cara yang dapat mereka pahami.

Peneliti kemudian mendesain intervensi Group Play Therapy yang berfokus pada kemampuan mengembangkan empati pada anak. Group Play Therapy yang diberikan yang mengandung nilai-nilai untuk mengajarkan anak-anak untuk mengembangkan kemampuan empati dan melakukan pembelajaran sosial kepada anak. Intervensi yang berfokus pada pembelajaran sosial dan emosional memiliki efektivitas untuk mengurangi perilaku agresi dan meningkatkan perilaku prososial (Schonert-Reichl, Oberle, Lawlor, Abbott \& Oberlander, 2012).

Setelah intervensi berakhir, beberapa anak merasa bahwa mereka belajar untuk dapat berbicara dengan sopan, menahan diri, menghargai teman dan merasa bahwa kebersamaan ketika bermain dapat membuat lebih akrab dengan teman-teman kelompok. Oleh karenanya dapat disimpulkan bahwa intervensi yang diberikan pada anak-anak memberikan pengaruh yang positif terhadap mereka. Perbedaan yang signifikan pada hasil akhir setelah intervensi berasal dari beberapa faktor yang berkaitan dengan keberhasilan terapi diantaranya proses jalannya terapi, partisipan yang kooperatif, setting terapi dan terapis.

Group Play Therapy adalah intervensi yang dilakukan secara berkelompok dimana terdapat berbagai permainan tradisional dan kreatif untuk membangun rasa empati para anggota kelompok. Anak-anak bergerak secara aktif, membangun komunikasi, taat pada peraturan, berusaha adil dan tidak curang, saling menghargai dan peduli terhadap temannya melalui Group Play Therapy. Hal tersebut selaras dengan penelitian sebelumnya yang menyatakan bahwa Group Play Therapy efektif dalam meningkatkan kemampuan empati, komunikasi sosial, dan kemampuan adaptasi pada anak-anak (Chinekesh et al., 2014).

Peningkatan kemampuan empati pada anak berdampak pada menurunnya perilaku agresi yang mereka miliki. Partisipan menunjukkan perilaku kerja sama dalam kelompok, berusaha untuk tidak egois dan saling menghargai dengan temannya sebagaimana yang dijelaskan oleh Jafari bahwa Group Play Therapy membantu anak-anak yang mempunyai perilaku bermasalah agar dapat terhindar dari masalah psikologis dan mengekspresikan interaksi yang lebih baik (Jafari et al., 2011). Zand, Mohsen, dan Nekah (2015) dalam studinya juga menyampaikan bahwa Group Play Therapy dapat mengurangi jumlah agresi pada sebagian besar anak-anak secara umum dan mengurangi agresi anak-anak prasekolah secara khusus.

Dalam proses terapi terjadi peningkatan pengetahuan dan pemahaman subjek tentang empati, kebersamaan, dan perilaku sosial. Hal tersebut menunjang terjadinya perubahan kemampuan empati pada kelompok eksperimen. Menurut Shoaakazemi, Javid, Tazekand, Rad, dan Gholami (2012) terapi bermain memberikan lingkungan di mana anak-anak mampu mengukur kemampuan mereka sendiri, mengekspresikan 
diri, dan belajar bagaimana menggunakan pengetahuan yang telah mereka peroleh juga untuk memaksimalkan kapasitas diri mereka. Pengetahuan dan pemahaman yang didapatkan oleh partisipan selama intervensi, dimana anak-anak mulai dapat belajar untuk displin, mengontrol ucapan, belajar untuk peduli dan menghargai teman yang lain. Anak-anak juga belajar untuk bekerja sama dalam kelompok, bersikap adil dan tidak egois serta patuh dengan peraturan yang berlaku selama terapi.

Faktor pendukung lain dalam keberhasilan terapi adalah peran terapis dan sikap kooperatif peserta terapi. Sebagaimana yang dijelaskan oleh Kool \& Lawver (2010) bahwa terapi bermain dapat digunakan sebagai sarana komunikasi antara anak dan terapis. Peran terapis untuk membangun kedekatan dengan anak-anak peserta terapi sangat diperlukan, permainan yang menyenangkan dan peraturan permainan yang jelas juga penting sehingga anak-anak mampu mengikuti intervensi dengan baik. Sikap kooperatif anak-anak dalam proses intervensi menjadi perhatian yang penting sehingga proses intervensi dapat berjalan sesuai dengan yang diharapkan.

Group Play Therapy memiliki manfaat yang banyak untuk anak-anak. Drewes \& Schaefer (2010) menjelaskan bahwa anak-anak dapat mengekspresikan pikiran dan perasaan mereka melalui kegiatan bermain lebih baik daripada dengan kata-kata saja. Pemberian Group Play Therapy dapat meningkatkan kreativitas, rasa kebersamaan, keinginan untuk menaati aturan yang berlaku, juga membangun rasa bersosialisasi bersama teman. Anak-anak akan merasa peduli dan menghargai teman-teman ataupun orang lain yang berada di sekitarnya seiring dengan meningkatnya kemampuan empati yang dimiliki. Hal tersebut kemudian berdampak pada menurunnya perilaku agresi dimana partisipan mampu mengikuti aturan, tidak egois, dan memaksakan kehendaknya pada teman yang lain.

\section{Simpulan}

Berdasarkan hasil penelitian dapat disimpulkan bahwa empati anak dapat ditingkatkan melalui Group Play Therapy. Dengan meningkatnya empati maka perilaku agresi anak dapat menurun. Hasil penelitian ini dapat diimplikasikan dalam program yang bertujuan untuk menurunkan perilaku agresi anak baik di rumah maupun di sekolah. Guru, orang tua maupun para praktiisi anak juga dapat mengaplikasikan ,permainan tradisional seperti gobak sodor, ular naga, ataupun bentengan kepada anak-anak untuk diterapkan di sekolah maupun di lingkungan rumah sebagai media pembelajaran untuk peningkatan empati. Bagi penelitian selanjutnya dapat melakukan penelitian ini pada setting yang berbeda, misalnya memasukkan program ini dalam pembelajaran kurikuler maupun ekstrakulikuler. Penerapan dalam setting komunitas juga dapat menjadi alternatif untuk penelitian selanjutnya. Dengan demikian peneliti dapat mengeksplorasi lebih dalam tentang faktor-faktor lain yang mempengaruhi proses intervensi yang dilakukan seperti kegiatan anak di luar sekolah. Faktor ekspresi emosi berdasarkan budaya yang dapat berbeda di setiap daerah juga dapat menjadi pertimbangan untuk penelitian selanjutnya. Variabel kontrol lain diharapkan dapat lebih dikendalikan sehingga mengurangi terjadinya bias pada penelitian, misalnya dengan dengan memberikan self-report kepada anak atau wali subjek penelitian agar memudahkan peneliti dalam mengevaluasi perkembangan terapi yang dialami anak-anak.

\section{Referensi}

Ali, N. H., \& Utami, D. S. (2013). Efektivitas Buku "Pelangi Hatiku" Dalam Menurunkan Agresi Siswa Sekolah Dasar. Jurnal Intervensi Psikologi $\quad$ (JIP), $\quad 5(1), \quad 59-74$. https://doi.org/10.20885/intervensipsikologi.vol5.iss1.art4

Bandura, A., Ross, D., \& Ross, S. A. (1961). Transmission of aggression through imitation of aggressive models. Journal of Abnormal and Social Psychology, 63(3), 575-582. https://doi.org/10.1037/h0045925

Botha, J. (2014). Relational aggression : the voices of primary school learners. 34(2), 1-15.

Breet, L., Myburgh, C., \& Poggenpoel, M. (2010). The relationship between the perception of own locus of control and aggression of adolescent boys. South African Journal of Education, 30(4), 511-526.

Cattanach, A. (2003). Book - Introduction to Play Therapy.

Chinekesh, A., Kamalian, M., Eltemasi, M., Chinekesh, S., \& Alavi, M. (2013). The Effect of Group Play Therapy on Social-Emotional Skills in Pre-School Children. Global Journal of Health Science, 6(2), $163-167$. https://doi.org/10.5539/gjhs.v6n2p163

Chinekesh, A., Kamalian, M., Eltemasi, M., Chinekesh, S., \& Alavi, M. (2014). The effect of group play therapy on social-emotional skills in pre-school children. Global Journal of Health Science, 6(2), $163-167$. https://doi.org/10.5539/gjhs.v6n2p163

Drewes, A. A., \& Schaefer, C. E. (2010). School-Based Play Therapy. https://doi.org/10.1002/9781118269701 
Ergün, S. (2012). The influence of violent TV cartoons watched by school children in Turkey. Acta Paulista de Enfermagem, 25(spe2), 134-139. https://doi.org/10.1590/S0103-21002012000900021

Hanan, F., Basaria, D., \& Yanuar, S. (2018). Penerapan Group Art Therapy Bagi Anak-Anak Masa Pertengahan yang Memiliki Kecenderungan Agresi Verbal. 2(1), 97-107.

Hudley, C., Britsch, B., Wakefield, W. D., Smith, T., Demorat, M., \& Cho, S. J. (1998). An attribution retraining program to reduce aggression in elementary school students. Psychology in the Schools, 35(3), 271-282. https://doi.org/10.1002/(SICI)1520-6807(199807)35:3<271::AID-PITS7>3.0.CO;2-Q

Jafari, N., Mohammadi, M. R., Khanbani, M., Farid, S., \& Chiti, P. (2011). Effect of play therapy on behavioral problems of maladjusted preschool children. Iranian Journal of Psychiatry, 6(1), 37-42.

Kozina, A. (2013). The LA aggression scale for elementary school and upper secondary school students: Examination of psychometric properties of a new multidimensional measure of self-reported aggression. Psihologija, 46(3), 245-259. https://doi.org/10.2298/PSI130402003K

Maryam, A. N., Mona, A. M., \& Akram, M. (2014). Cognitive-Behavioral Method on Social Adjustment of. 3(12), 356-363.

Milani, L., Camisasca, E., Caravita, S. C. S., Ionio, C., Miragoli, S., \& Di Blasio, P. (2015). Violent Video Games and Children's Aggressive Behaviors. SAGE Open, 5(3), 215824401559942. https://doi.org/10.1177/2158244015599428

Overgaauw, S., Rieffe, C., Broekhof, E., Crone, E. A., \& Güroglu, B. (2017). Assessing empathy across childhood and adolescence: Validation of the empathy questionnaire for children and adolescents (EmQue-CA). Frontiers in Psychology, 8(MAY), 1-9. https://doi.org/10.3389/fpsyg.2017.00870

Parfilova, G. G. (2016). Managing and preventing aggressiveness in primary school children. Mathematics Education, 11(4), 921-931.

Pingault, J. B., Côté, S. M., Lacourse, E., Galéra, C., Vitaro, F., \& Tremblay, R. E. (2013). Childhood Hyperactivity, Physical Aggression and Criminality: A 19-Year Prospective Population-Based Study. PLoS ONE, 8(5), 13-15. https://doi.org/10.1371/journal.pone.0062594

Ray, D. C., Blanco, P. J., Sullivan, J. M., \& Holliman, R. (2009). An Exploratory Study of Child-Centered Play Therapy With Aggressive Children. International Journal of Play Therapy, 18(3), 162-175. https://doi.org/10.1037/a0014742

Reef, J., Diamantopoulou, S., Van Meurs, I., Verhulst, F. C., \& Van Der Ende, J. (2011). Developmental trajectories of child to adolescent externalizing behavior and adult DSM-IV disorder: Results of a 24-year longitudinal study. Social Psychiatry and Psychiatric Epidemiology, 46(12), 1233-1241. https://doi.org/10.1007/s00127-010-0297-9

Russ, W. S. (2004). Play in Child Development and Psychotherapy. In Psychotherapy.

Sandra Jo Wilson, and Mark W. Lipsey. (2008). School-Based Interventions for Aggressive and Disruptive Behavior: Update of a Meta-Analysis. Am J Prev Med. Author Manuscript; Available in PMC 2008 August 1., 33, 1-29.

Sarpoulaki, B., \& Kolahi, P. (2016). The Effectiveness of Play Therapy on Aggression Index , a Clinical Trial. 7 , 1308-1312.

Schonert-Reichl KA, Oberle E, Lawlor MS, Abbott D, T. K., \& Oberlander TF, D. A. (2012). Dialectical Behavior Therapy with Suicidal AdolescentsEnhancing Cognitive and Social-Emotional Development Through a Simple-to-Administer Mindfulness-Based School Program for Elementary School Children: A Randomized Controlled Trial Kimberly. Journal of Child and Family Studies, 19(2), $239-255$. https://doi.org/10.1037/a0038454.Enhancing

Scrimgeour, M. (2007). Empathy and Agression: A Study of the Interplay Between Empathy and Agression in Preschoolers. 1, 1-36. https://doi.org/10.1017/CBO9781107415324.004

Siddiqah, L. (2010). Pencegahan dan Penanganan Perilaku Agresif Remaja Melalui Pengelolaan Amarah (Anger Management). Jurnal Psikologi, 37(1), 50-64.

UNICEF. (2006). The Child Friendly School manual. 1-244.

Vitaro, F., Brendgen, M., \& Tremblay, R. E. (2002). Reactively and proactively aggressive children: Antecedent and subsequent characteristics. Journal of Child Psychology and Psychiatry and Allied Disciplines, 43(4), 495-505. https://doi.org/10.1111/1469-7610.00040

Wiley, J. (2001). Game Play Therapeutic Use of Childhood Games (C. Schaefer \& S. E. Reid (eds.); Second).

Zand, E. K., Mohsen, S., \& Nekah, A. (2015). An Investigation into the Effect of Group Play Therapy on Aggression Reduction in Male Preschool Students. 2(5), 78-87. 